\title{
Perhitungan Laba Rugi Model Bagi Hasil Usaha Peternakan Sapi pada Bumdes Banna Lhokseumawe
}

\author{
Dasmi Husin*1, Hilmi², Azhar $^{3}$ \\ 1,2Jurusan Tata Niaga, Politeknik Negeri Lhokseumawe \\ ${ }^{3}$ Jurusan Teknik Elektro, Politeknik Negeri Lhokseumawe

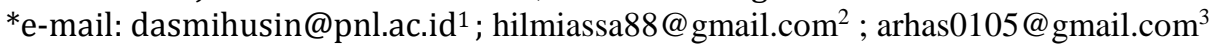

\begin{abstract}
This community service activity was carried out at Bumdes (village community owned company) of Banna in Paya Punteut Village, Muara Dua District - Lhokseumawe, Aceh. This village-owned company is known to be engaged in cattle fattening. The motivation and enthusiasm to develop from the management of BUMDes Banna is very high, but the managerial ability of Bumdes management is still very limited. Bumdes, who were expected to grow forward, turned out to be suffering from many problems. One of the problems is when the profit sharing is not proportional. The operating costs incurred are not appropriate. Livestock care work is given to a group of people on the condition that Bumdes bears all operational costs. Profit sharing is based on the revenue sharing system where Bumdes gets a $40 \%$ portion of the sales of cows. The service method used in the dedication of the application of science and technology is a participatory method, namely by making continuous observations, speeches, and direct demonstration (demonstration) methods. This activity is capacity building assistance for six months. The focus is on strengthening productivity and management such as compiling financial reports, business visibility, and strengthening archives management. The results of community service activities indicate that the profit sharing system has not fully met the standard accounting standard format, especially in the preparation of the income statement. In order for Bumdes to no longer feel that it is making a profit, but in fact it is a loss, the formulation of the AD-ART (regulation of company village) needs to be revised with the approval of Bumdes stakeholders through village meetings. Furthermore, the preparation of financial statements must be based on applicable accounting standards.
\end{abstract}

Keywords:Bumdes, Revenue Sharing, Results, Finance

\begin{abstract}
Abstrak
Kegiatan pengabdian masyarakat ini dilaksanakan pada Bumdes Banna di Desa Paya Punteut Kecamatan Muara Dua - Lhokseumawe, Aceh. Perusahaan milik desa ini diketahui bergerak dalam bidang usaha penggemukan sapi. Motivasi dan semangat untuk berkembang dari manajemen BUMG Banna sangat tinggi, namun kemampuan manajerial pengelolaan Bumdes masih sangat terbatas. Bumdes yang diharapkan tumbuh maju, ternyata banyak mendera permasalahan. Salah satu masalahnya adalah pada saat bagi hasil usaha yang tidak proporsional. Biaya operasional yang ditimbulkan tidak sesuai. Pekerjaan perawatan ternak diberikan kepada sekelompok masyarakat dengan ketentuan Bumdes menanggung semua biaya operasional. Pembagian bagi hasil berdasarkan sistem revenue sharing dimana Bumdes mendapatkan porsi $40 \%$ dari hasil penjualan sapi. Metode pengabdian yang digunakan dalam pengabdian penerapan ipteks ini adalah metode partisipatif yaitu dengan cara melakukan pengamatan berkelanjutan, orasi, dan metode demonstrasi (peragaan) langsung. Kegiatan ini bersifat asistensi penguatan kemampuan selama enam bulan. Fokusnya pada penguatan produktivitas dan manajemen seperti menyusun laporan keuangan, visibilitas usaha, dan penguatan manajemen kearsipan. Hasil kegiatan pengabdian masyarakat menunjukkan bahwa sistem bagi hasil belum sepenuhnya memenuhi format standar akuntansi yang baku terutama pada penyusunan laporan laba rugi. Agar Bumdes tidak lagi merasa memperoleh laba, namun kenyataannya rugi, maka rumusan ADART perlu direvisi dengan mendapatkan persetujuan dari pemangku kepentingan Bumdes melalui musyawarah desa. Selanjutnya penyusunan laporan keuangan harus berdasarkan standar akuntansi yang berlaku.
\end{abstract}

Kata kunci: Bumdes, Pembagian Penghasilan, Hasil, Keuangan

\section{PENDAHULUAN}

Sejak dikeluarkan undang-undang Nomor 6 tahun 2014 tentang desa, pembangunan desa di seluruh Indonesia telah banyak berubah. Begitupun, program pemerintah ini bukan berarti berjalan mulus di lapangan. Banyak kendala teknis di desa dan pada umumnya selalu disebabkan 
oleh permasalahan sumber daya manusia. Berbagai terobosan telah diambil pemerintah untuk mengangkat harkat martabat dan kesejahteraan warga desa. Salah satunya dengan mendirikan perusahaan desa yakni Badan Usaha Milik Desa (Bumdes). Disyaratkan bahwa satu desa harus memiliki satu Bumdes. Unit usaha yang berorientasi bisnis ini nantinya akan bermanfaat untuk masyarakat desa.

Menurut Amelia Sri Kusuma Dewi. (2014) dan Chindy Sasauw, dkk (2018) menyatakan bahwa berjalannya roda organisasi BUMDes dan juga neraca organisasi yang terus mengalami peningkatan akan membantu menyelesaikan tugas dan tanggung jawab pengelola di bidang keuangan. Kehadiran BUMDes berdampak langsung pada masyarakat walaupun memang belum menyentuh masyarakat secara keseluruhan. Badan Usaha Milik Desa merupakan salah satu alternatif untuk meningkatkan ekonomi di pedesaan.

Salah satu Badan Usaha Milik Gampong (BUMG) yang menjadi kajian adalah BUMG Banna yang terletak di desa Paya Punteut Kecamatan Muara Dua, Lhokseumawe, Aceh. BUMG Banna didirikan pada tahun 2017. Bumdes ini dinyatakan Bumdes terbaik di Kecamatan Muara Dua karena sebagian laba usahanya mampu diberikan untuk menambah Pendapatan Asli Desa (PADes). Segmentasi usaha yang dipilih bergerak di bidang penggemukan sapi. Pada tahun 2018 pemerintah Desa Paya Punteut telah mengalokasikan dana untuk permodalan awal BUMG sejumlah Rp.200.000.000. Dari penyertaan modal tersebut, BUMG telah membeli 18 ekor lembu, mendirikan kandang, pemasangan instalasi listrik, air, dan peralatan pendukung lainnya. Beberapa bagian dari penyertaan modal tersebut dialokasikan secara khusus untuk biaya operasional pengurus.

Pengurus BUMG tidak terlibat langsung dalam pengelolaan ternak di lapangan. Pekerjaan ini diserahkan kepada kelompok masyarakat dengan sistem bagi hasil (mawah). Kelompok ini bekerja penuh untuk merawat sapi-sapi desa. Sebagai imbalannya peternak akan mendapatkan bagi hasil sebesar $60 \%$, sedangkan BUMG Banna mendapat porsi $40 \%$. Setiap penjualan satu ekor lembu, langsung dibagi hasilnya. Pembagian tersebut tentu setelah mengurangi modal pembelian lembu, baru kemudian dibagi $60: 40$.

Usaha Bumdes yang aktif bergerak di bidang peternakan sapi di Lhokseumawe Aceh tercatat hanya 5 Bumdes saja. Awalnya banyak Bumdes memilih segmentasi usaha dibidang ini, namun belakangan banyak gagal akibat salah pengelolaannya. Padahal potensi peternakan sapi sangat prospektif di Aceh. Setiap tahun persediaan lembu laku terjual tanpa bersisa. Sementara untuk pakan ternak tersedia mencukupi. Karena Lhokseumawe juga memiliki area lahan rumput hijau yang luas. Apalagi sebagian peternak telah menguasai teknik pengolahan pakan fermentasi dan silase. saat musim hujan atau musim kemarau peternak tindak merasa kuatir akan persediaan pakan, karena peternak telah menguasai teknik penyimpanan pakan ini.

Kekhawatiran atas kebangkrutan usaha seperti tersebut diatas sebenarnya juga sedang dialami oleh BUMDES Banna. Pengurus Bumdes merasa usahanya berhasil, memperoleh laba yang tinggi, namun pengurus juga mencurigai sebenarnya telah mengalami kerugian. Hal ini dibuktikan dengan modal penyertaan Bumdes semakin berkurang. Sikap ketidakpastian apakah telah menerima laba atau rugi seperti ini telah berlangsung selama 2 tahun tanpa kejelasan yang pasti. Laba tapi sebenarnya rugi. Namun satu hal yang pasti bahwa perusahaan desa ini mengaku telah berkontribusi penuh atas penerimaan bagi hasil sebesar 40\%. Akumulasi dana yang diperoleh dari bagi hasil 40\%, telah disalurkan untuk pemasukan PAD desa, cadangan modal berikutnya, untuk pengurus BUMDes, pengawas, dan dana sisihan untuk corporate social responsibility (CSR) kegiatan pemuda desa.

Semua kebijakan yang dijalankan tidak terlepas dari apa yang telah dirumuskan dalam anggaran dasar rumah tangga (AD-ART) Bumdes. Penyusunan tata tertib pengelolaan ini dirancang dan dibahas bersama antara pengurus, aparatur desa, dan tuha peut (Badan Permusyawaratan Masyarakat Desa). Dari hasil observasi awal diketahui AD-ART Bumdes Banna hanya mengatur prosedur teknisnya saja. Regulasi tersebut tidak cukup kuat mengatur tentang pencatatan dan pelaporan keuangan. Misalnya tata cara pembagian bagi hasil usaha. Selama ini 
Bumdes mempraktikkan laba langsung dibagi sebelum dikurangi biaya operasional. Biaya operasional seperti biaya perawatan ternak, biaya listrik, dan biaya gaji pengurus justru diambil dari modal penyertaan Bumdes dari desa.

Akibatnya dana penyertaan modal BUMG semakin terkuras. Laba atau rugi usaha, pengurus tetap memperoleh penghasilan yang diambil dari dana penyertaan tersebut. Begitu juga halnya dengan hasil pembagian $40 \%$ dari laba usaha dengan peternak. Sebanyak $10 \%$ diantaranya dana tersebut diperuntukkan untuk pengurus. Semuanya telah sesuai dengan ketentuan. Porsi pembagian laba untuk BUMG terdiri dari banyak pihak yang menikmatinya. Dengan adanya perspektif adil, maka laba tidak saja dinikmati oleh sekelompok kecil pemilik perusahaan, tetapi juga dapat dinikmati oleh seluruh stakeholder.

Praktik seperti ini merupakan hal yang salah namun tidak ada pihak yang disalahkan karena pengurus Bumdes telah menjalankan fungsinya sesuai ketentuan AD-ART. Terlepas dari hal itu, pengelolaan keuangan seperti ini tentu berdampak buruk bagi kelangsungan usaha (going concern). Istilah laba sebenarnya rugi akan terus berlangsung jika tidak ada upaya perbaikan. Bumdes pun sangat potensial bangkrut. Oleh karena itu banyak hal yang harus diperbaiki terutama peninjauan ulang AD-ART. Penyusunan kembali laporan keuangan Bumdes yang benar mengikuti standar akuntansi yang baku Dapat digambarkan pula kondisi dan potensi wilayah dari segi fisik, sosial, ekonomi, maupun lingkungan yang relevan dengan kegiatan yang dilakukan.

Dalam suatu pembiayaan ada yang disebut margin. Menurut Erni Susana (2011) margin adalah merupakan persentase keuntungan yang diharapkan dalam satu tahun Sistem bagi hasil yang proporsional dapat diterapkan ke segala sektor perekonomian yang dapat memberikan keuntungan bersama. Margin pembagian tersebut dapat dilakukan dengan dua metode yaitu metode profit sharing dan revenue sharing. Pemilihan metode bagi hasil harus diungkapkan secara jelas dan tercatat dalam AD-ART Bumdes.

Selain pemahaman terhadap margin bagi hasil, pihak-pihak yang terlibat dalam legalitas BUMDes, mestinya juga harus jeli melihat peluang usaha. Peluang usaha yang memanfaatkan potensi desa. Boni Saputra, dkk (2020) menyatakan; Terbatasnya pemahaman pemerintahan desa, perangkat BUMDes, dan stakeholder terkait penguatan kelembagaan (capacity building) Badan Usaha Milik Desa telah mengakibatkan banyak potensi desa tidak dapat diolah menjadi unit bisnis yang kreatif dan menguntungkan.

Saat ini Bumdes merupakan entitas berbadan hukum. Kedudukannya menjadi setara dengan pelaku bisnis yang lain, namun secara kelembagaan pengelolaan manajerialnya masih sangat lemah. Berdasar Peraturan Pemerintah Nomor 11 Tahun 2021 tentang Badan Usaha Milik Desa (BUMDes), diperlukan adanya upaya pemanfaatan aset desa untuk menciptakan nilai tambah yang nantinya berguna untuk peningkatan kesejahteraan warga.

Artikel ini merupakan salah satu upaya untuk memenuhi harapan tersebut. Dengan adanya Program Kemitraan Masyarakat (PKM) yang didanai oleh Ristek Brin Kemendikbud dan telah dilaksanakan oleh Politeknik Negeri Lhokseumawe, maka hasilnya secara spesifik dapat membantu persoalan kelembagaan Bumdes. Selain itu hasil penelitian ini juga dapat menambah khazanah referensi penelitian tentang Bumdes yang ditengarai masih terbatas. Artikel ini secara luas diharapkan mampu memberi kontribusi positif untuk pencapaian tingkat kemandirian Bumdes di Indonesia.

\section{METODE}

Pelaksanaan pengabdian masyarakat ini telah dilakukan pada BUMG Desa Paya Punteut Kecamatan Muara Dua Kota Lhokseumawe, Aceh. Bumdes ini dinyatakan Bumdes bereputasi baik di tingkat pemerintah Kota Lhokseumawe Aceh. Kontribusi laba usahanya telah nyata diberikan untuk pemasukan kas Pendapatan Asli Desa (PADes) Desa Paya Punteut. Metode pengabdian yang digunakan yaitu metode partisipatif. Peneliti melakukan pengamatan berkelanjutan secara 
langsung terhadap perilaku atau kebiasaan pengurus Bumdes dalam mengelola manajemen usahanya. Selain itu juga dilakukan metode orasi dan metode demonstrasi (peragaan) langsung. Kegiatan ini lebih bersifat asistensi penguatan kemampuan pengurus Bumdes setempat sehingga dari kegiatan tersebut diketahui permasalahan dan solusi yang dikemukakan. Pelaksanaan kegiatan dilakukan selama enam bulan berturut-turut mendampingi mitra dalam hal penguatan di bidang produktivitas dan manajemen usaha seperti penguatan kewirausahaan, penyusunan laporan keuangan, pengelolaan manajemen kearsipan.

\section{HASIL DAN PEMBAHASAN}

Kegiatan PKM ini telah dilaksanakan sejak Juli - Desember 2020 di Bumdes Banna Desa Paya Punteut Kecamatan Muara Dua, Pemerintahan Kota Lhokseumawe, Aceh. Pihak-pihak yang terlibat dalam kegiatan ini adalah tim pengabdian dari Politeknik Negeri Lhokseumawe, mahasiswa pendamping dari Jurusan Tata Niaga, aparatur desa, pengurus Bumdes Banna, dan mitra Bumdes lain sebagai tempat pelatihan fermentasi dan silase pakan ternak.

Sebelum dilakukan kegiatan pengabdian masyarakat, kemampuan mitra binaan masih sangat terbatas. Begitupun, semangat untuk tumbuh dan berkembang sangatlah tinggi. Untuk melihat kondisi awal dan kondisi setelah penguatan dapat dilihat pada tabel 1 dibawah ini:

Tabel 1. Pemetaan Kemampuan Mitra Binaan

\begin{tabular}{cccc}
\hline Segmentasi & Kondisi Awal & Kecakapan & Pengetahuan \\
\hline Produktivitas & Lemah & Sedang & Sedang \\
Laporan Keuangan & Tidak sesuai & Sesuai Standar & Baik \\
Visibilitas Usaha & Kurang & Baik & Kurang \\
Manajemen Kearsipan & Buruk & Baik & Baik \\
\hline
\end{tabular}

Point penyebab rendahnya kecakapan pengelola Bumdes adalah karena latar belakang pendidikan pengurus tidak cukup mendukung untuk menerapkan konsep manajemen terintegrasi. Salah satu contohnya kemampuan manajemen dalam orientasi marketing dan penyusunan laporan keuangan. Proses penguatan kewirausahaan dan pengelolaan kearsipan kantor dapat dilihat pada gambar 1 berikut ini:
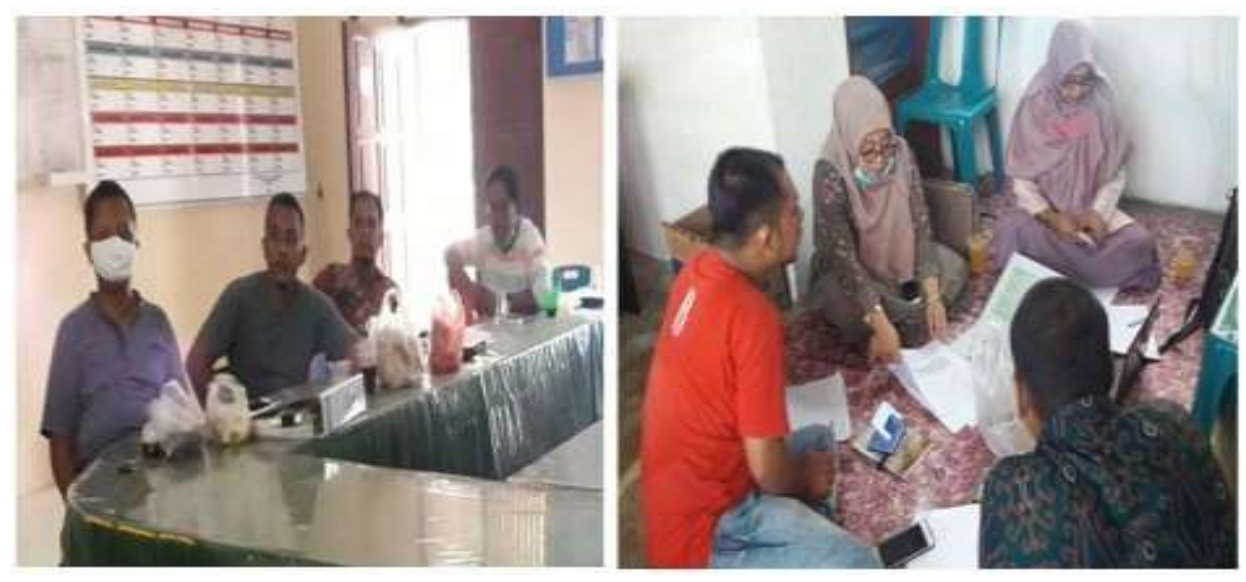

Gambar 1. Penguatan kewirausahaan dan manajemen keasipan mitra

Sejak BUMG Banna didirikan ternyata pengurus belum pernah menyusun laporan keuangan. Semua transaksi telah dicatat di buku kas dan buku bank setiap bulannya, tetapi kedua 
buku tersebut sebenarnya bukanlah dianggap sebagai laporan keuangan. Ini hanya sebagai media pencatatan saja. Pada buku kas transaksi keuangan dicatat dengan cara menghimpun semua transaksi. Beberapa transaksi telah terjadi namun sulit ditelusuri karena tidak dicatat. Misalnya akun pendapatan bunga atau pengeluaran untuk biaya bank. Padahal, jika pengelola Bumdes membukukan transaksi sesuai dengan standar akuntansi yang berlaku, maka informasi keuangan yang dihasilkan dapat dijadikan bahan pengambilan keputusan yang valid, Carl S, Warren, dkk. (2017).

Perlu diketahui bahwa apakah perusahaan mampu atau tidak memperoleh pendapatan, seluruh pihak yang terlibat (pengurus, pengawas, dan kepala desa) tetap saja memperoleh gaji yang dari alokasi dana yang telah dicadangkan. Baik biaya operasional maupun biaya administrasi dananya tetap diambil dari alokasi dimaksud. Ketentuan ini merupakan kesepakatan awal saat pendirian BUMG dan ketentuan itu sudah dirumuskan ke dalam AD-ART.

Padahal pada tahun 2018 sebagai tahun kedua beroperasi, tidak ada transaksi penjualan lembu kecuali hanya sedikit menerima pendapatan dari bunga dan sedikit pengeluaran biaya bank. Pada tahun ini pula banyak biaya biaya operasional yang dikeluarkan, namun karena biaya tersebut tidak diakui sebagai unsur pengurang laba kotor, maka BUMG mengklaim diri tidak mengalami kerugian dan juga tidak memperoleh laba pada tahun tersebut. Anggapan seperti ini justru jika dihitung menggunakan format laporan laba rugi yang sebenarnya, maka sesungguhnya pada tahun 2018 BUMG Banna mengalami kerugian. Seluruh pengeluaran untuk biaya operasi dan biaya administrasi yang mengurangi modal penyertaan dicatat kembali menjadi mengurangi laba kotor (gross profit).

Oleh karena setiap pengeluaran tidak diambil dari hasil usaha (laba kotor), maka pos pengeluaran biaya tidak dicatat sama sekali di dalam laporan laba rugi. Akibatnya perusahaan terkesan tidak pernah mengalami kerugian karena tidak melaporkan biaya dalam laporan laba ruginya. Ketentuan seperti ini sudah harus diubah mengikuti penyajian laporan keuangan yang standar.

Pada tahun 2019 BUMG Banna tidak menerima penyertaan modal dari alokasi dana desa. Aktivitas di tahun tersebut praktis hanya mengelola sisa dana dari tahun sebelumnya. Begitupun, pada tahun 2019 unit usaha penggemukan sapi ini berhasil menjual lembu sebanyak 8 ekor. Praktik tidak mencatat biaya sebagai pengurang unsur laba kotor di tahun ini masih saja dilakukan. Pengurus langsung menyerahkan dana sebanyak $60 \%$ setelah dikurangi pangkal (modal pembelian lembu) kepada pengelola ternak. Sebanyak $40 \%$ berikutnya ditahan untuk BUMG. Nantinya dana $40 \%$ tersebut juga akan dibagi-bagikan kepada yang berhak sesuai porsi yang telah disepakati. Bumdes kembali mengklaim bahwa usahanya mampu memperoleh laba yang tinggi.

Sebenarnya ada dua cara bagi hasil yang dapat dilakukan oleh BUMG Banna yaitu profit sharing dan revenue sharing. Margin laba menggunakan profit sharing lebih berimbang kepentingannya antara pengelola dan pemilik modal. Dengan menggunakan sistem profit sharing maka perhitungan bagi hasil didasarkan kepada hasil bersih dari total pendapatan setelah dikurangi dengan biaya-biaya yang dikeluarkan untuk memperoleh pendapatan. Kenyataannya, pengelola tidak akan mungkin ikut menanggung biaya operasional yang tidak berkaitan dengan proses usahanya meskipun biaya tersebut tetap berkaitan dengan upaya perolehan pendapatan. Selanjutnya revenue sharing adalah perhitungan bagi hasil didasarkan kepada total pendapatan yang diterima sebelum dikurangi dengan biaya-biaya (gross profit). Pemilik modal biasanya akan memperoleh porsi pembagian yang lebih besar dari pengelola usaha, Ma'rifatun (2015).

Dari dua model tersebut diatas, BUMG Banna menggunakan sistem revenue sharing. Laba usaha langsung dibagi ketika penjualan lembu selesai dilakukan. tetapi janggalnya kesepakatan desa memutuskan persentase pembagian margin laba untuk pengelola lebih besar daripada pemilik modal (BUMDes). Kenyataannya cara seperti itu BUMDes telah mengalami kerugian selama dua tahun berturut-turut. Bahkan jumlah dana saat ini di BUMDes tidak sama lagi dengan jumlah dana saat ditransfer dari rekening desa. 


\section{Sistem Bagi Hasil yang Proporsional}

Sistem penggemukan sapi pada BUMG Banna menggunakan sistem bagi hasil. Sebanyak $60 \%$ untuk peternak dan 40\% untuk BUMG. Dari setiap hasil penjualan lembu langsung dikurangi dengan modal pembelian lembu lalu dan sisanya dianggap laba. Kemudian laba tersebut langsung dibagi. Nilai $40 \%$ untuk porsi BUMG tersebut dibagi lagi kepada pihak-pihak yang telah dicantumkan di dalam AD-ART. Jika laba untuk BUMG dianggap 100\%, maka dana $100 \%$ itu nantinya dibagi lagi untuk PAD Desa 40\%, untuk penyertaan modal kembali (laba ditahan) 20\%, komisaris (kepala desa) 10\%, pengawas (BPM/Tuha peut) 10\%, jajaran Direksi BUMG 10\%, dan untuk alokasi corporate social responsibility (CSR) atau bantuan untuk kegiatan pemuda desa sebesar $10 \%$. Untuk porsi penyertaan modal kembali $20 \%$ dananya digunakan untuk membiayai berbagai keperluan usaha.

Idealnya penyertaan modal kembali (laba ditahan) paling kurang sejumlah harga perolehan yang telah dikeluarkan. Idealnya bahkan semestinya harus diatas harga pokok pembelian sebelumnya atau harus dinaikan $10 \%$. Hal ini agar dapat mengantisipasi terjadi naiknya (inflasi) harga beli lembu di tahun berikutnya.

Disini pembagian $60 \%$ untuk pengelola lembu dinilai terlalu memberatkan pihak pemilik (Bumdes Banna) karena seluruh biaya ditanggung sepenuhnya oleh pemilik (Bumdes). Pengeluaran untuk biaya perawatan, biaya administrasi, biaya listrik, cadangan pajak, termasuk biaya gaji pengurus, dan lain-lain terpantau ditanggung sepenuhnya oleh manajemen Bumdes. Jika persentase pembagian tidak bersedia dirubah, maka seharusnya biaya operasional peternakan harus menanggung bersama. Biaya ini merupakan biaya operasional yang menyangkut dengan peternakan sapi. Tidak termasuk biaya administrasi, pemasaran dan lainlain.

Saat menyusun laporan laba rugi BUMG Banna idealnya disusun berdasarkan metode pencatatan perpetual. Dimana biaya atau harga pokok penjualan yang ditampilkan di laporan laba rugi langsung mengurangi penjualan. Tidak perlu lagi dibentuk pos pembelian, persediaan awal, dan persediaan akhir seperti halnya pencatatan metode periodik. Alasan menggunakan metode inipun oleh karena frekuensi transaksi (pencatatan) dan output persediaan lembu tidak banyak dan modal pembelian (harga pokok penjualan) lembu langsung dikurangi pada saat dijual, maka metode perpetual adalah metode yang paling tepat digunakan.

Khusus untuk pengeluaran bagi hasil 60\% dibenarkan dianggap sebagai biaya bagi hasil. Pos ini tentu dicantumkan dalam kelompok biaya. Hal ini dilakukan karena pembagian $60 \%$ tersebut diberikan bukan setelah perusahaan memperoleh laba bersih, tetapi dilakukan pada saat penjualan selesai dilakukan. Pengeluaran tersebut otomatis dianggap sebagai biaya bagi hasil. Biaya ini dimunculkan dan di laporan laba rugi sebagai bagian dari pos biaya operasional.

Prinsip berkeadilan melarang adanya unsur riba, kezaliman, maysir, gharar, dan haram. Dalam sistem bagi hasil pada entitas syariah, semua pihak harus menjunjung prinsip syariah. Pemilihan profit sharing maupun revenue sharing ditentukan berdasarkan kesepakatan masingmasing pihak yang tertuang dalam AD-ART BUMG. Regulasi ini dirumuskan oleh aparatur desa, Badan Permusyawaratan Desa (tuha peut), pengelola usaha, dan pengurus BUMG dengan menjunjung prinsip keadilan, terbuka, jelas, dan tidak mengandung unsur-unsur negatif yang terselubung.

Hasil temuan atau hasil penelitian seperti ini mengindikasikan bahwa Bumdes yang dianggap berkembang saja masih banyak kendala dari sisi penguatan kelembagaan. Terutama pada sisi manajemen, produktivitas, jalinan komunikasi antar pemangku kepentingan, dan kemampuan teknologi digitalisasi. Khusus pada konsep bagi hasil, jika ketidakpahaman terhadap sistem dan pelaporan akuntansi yang seharusnya dipakai, maka faktor ini akan menjadi pemicu utama terhentinya keberlanjutan operasional Bumdes. 


\section{KESIMPULAN}

Eksistensi Bumdes sangat bermanfaat bagi masyarakat desa bilamana Bumdes tersebut tidak menjadi beban baru bagi desa. Bumdes merupakan perusahaan milik desa yang berorientasi bisnis. Meskipun unsur sosial pedesaan lebih tinggi, tetapi orientasi profit motif tetap harus diutamakan. Untuk menyikapinya diperlukan motivasi yang tinggi, kemampuan teknologi digitalisasi, sinergitas usaha dan pendampingan secara teknis.

Dalam hal penyusunan laporan laba rugi, BUMDes tetap harus mengutamakan prosedur akuntansi. Sebab seberapapun dana yang diterima wajib dipertanggungjawabkan secara transparan. Menyusun laporan keuangan seperti penyusunan laporan laba rugi haruslah sesuai standar dapat melegalkan proses pertanggungjawaban pengelola Bumdes. Kedepan pembagian porsi laba bagi hasil tidak dilakukan lagi sebelum dikurangi biaya-biaya operasional. Lakukan sesuai metode profit sharing. Selanjutnya AD-ART Bumdes Banna juga perlu ditinjau kembali. Pengurus Bumdes, aparatur desa, Badan Permusyawaratan Desa (tuha peut) perlu bersinergi memikirkan kelangsungan usaha Bumdes menggarap berbagai potensi desa untuk dikomersilkan.

Dalam pembagian hasil usaha sangat perlu diperhatikan hasil kesepakatan di awal. Sukma Uli Nuha dan Endah Masrunik. (2017) menyatakan bahwa akad kerja sama antara dua belah pihak (penyedia modal dan pengelola modal) akan membantu pemerintahan desa dalam meningkatkan pendapatan dan juga akan membantu mensejahterakan masyarakat. Pemilihan strategi dan keputusan yang tepat seperti menggunakan konsep mudharabah akan menguntungkan pemilik dan pengelola usaha. Dalam situasi keterpurukan usaha, sangat diperlukan strategi tepat untuk keluar dari krisis. Bumdes sebagai pelaku usaha kecil dan menengah (UKM) diharapkan bangkit kembali untuk dapat beraktivitas di dalam tatanan kenormalan baru (new normal).

Semangat untuk maju melalui pendirian perusahaan desa perlu diapresiasi, namun penguatan secara teknis juga harus dilakukan. Bagaimanapun upaya menciptakan kesejahteraan masyarakat desa adalah hal yang penting, namun pengendalian uang milik negara jauh lebih penting dilakukan. Agar metode bagi hasil memenuhi harapan semua pihak, manajemen Bumdes perlu mendiskusikannya kembali dalam forum musyawarah desa bersama stakeholder mengikat seperti aparatur desa, tuha peut (Badan Permusyawaratan Desa), dan pengurus Bumdes sendiri. Hasilnya dapat dituangkan dalam peraturan desa atau setidaknya dalam AD-ART revisi yang baru.

\section{UCAPAN TERIMA KASIH}

Penulis mengucapkan terima kasih kepada Ristek Brin yang telah memberi dukungan finansial terhadap kegiatan program kemitraan masyarakat (PKM) tahun 2020 untuk Politeknik Negeri Lhokseumawe.

\section{DAFTAR PUSTAKA}

Amelia Sri Kusuma Dewi. (2014). Peranan Badan Usaha Milik Desa (Bumdes) sebagai upaya dalam Meningkatkan Pendapatan Asli Desa (Pades) serta Menumbuhkan Perekonomian Desa. Journal of Rural and Development Volume V No. 1 Februari 2014.

Boni Saputra, Hidayatul Fajri, Pratiwi Nurhabibi. (2020). Penguatan Kelembagaan Badan Usaha Milik Nagari (BUM-Nag) Sebagai Upaya Peningkatan Ekonomi Nagari. DINAMISIA: Jurnal Pengabdian Kepada Masyarakat. DINAMISIA. Jurnal Pengabdian Kepada Masyarakat Vol. 4, No.4 Desember 2020, Hal 743 - 753.

Carl S, Warren, dkk. (2017). Pengantar Akuntansi. Edisi 25. Jakarta :PT Salemba Empat https://journal.unilak.ac.id/index.php/dinamisia/article/view/4507/2359

Chindy Sasauw, Ronny Gosal, Welly Waworundeng. (2018). Efektivitas Badan Usaha Milik Desa (Bumdes) dalam Meningkatkan Masyarakat di Desa Lenganeng Kecamatan Tabukan Utara Kabupaten Kepulauan Sangihe. Jurnal Eksekutif. Vol 1, No 1 (2018). https://ejournal.unsrat.ac.id/index.php/jurnaleksekutif/article/view/21940 
Dasmi Husin (2016). Perancangan Aplikasi Akuntansi Keuangan Sederhana untuk Aparatur Pemerintahan Gampong dengan Menggunakan Visual Basic - Microsoft Acces 2010. Laporan Penelitian. Hibah Bersaing. Politeknik Negeri Lhokseumawe.

Erni Susana, Annisa prasetyanti. (2011). Pelaksanaan dan Sistem Bagi Hasil Pembiayaan Almudharabah pada Bank Syaria. Jurnal Keuangan dan Perbankan, Vol.15, No.3 September 2011, hlm. 466-478.

Hery Hidayat. (2011). Aplikasi Akuntansi Dengan Excel Bisa Diterapkan di Microsoft Excel 2003, 2007, 2010. Jakarta: Dunia Komputer.

Kementerian Riset, Teknologi, dan Pendidikan Tinggi. (2019). Panduan Penelitian dan Pengabdian Kepada Masyarakat Edisi XII. Edisi Revisi 2019. Direktorat Riset dan Pengabdian Masyarakat. Direktorat Jenderal Penguatan Riset dan Pengembangan.

Ma'rifatun, Akbar Yusuf, Herni Sunarya. (2015). Analisis Sistem Penerapan Bagi Hasil terhadap Perolehan Laba Berdasarkan Prinsip Syariah. Jurnal Akuntansi (JA) Vol. 2, No. 3, September 2015. Hal. 29s/d 41.

Sukma Uli Nuha dan Endah Masrunik. (2017). Transparansi Sisa Hasil Usaha Bumdes dalam Perspektif Akuntansi Syari'ah sebagai Strategi Desa Guna Meningkatkan Pendapatan Desa (Studi kasus pada Bumdes "Jaya Lestari" desa Jatinom, Kecamatan Kanigoro, Kabupaten Blitar). Prosiding Seminar Nasional dan Call for Paper Ekonomi dan Bisnis (Snaper-Ebis 2017) Jember, 27-28 Oktober 2017 (hal 52-57) ISBN : 978-602-5617-01-0. 